\title{
Correction to: Finite Element Analysis of Shell-First and Longitudinally Reinforced Frame-Based Wooden Ships
}

\author{
Nathan Helfman ${ }^{1}$ (D) $\cdot$ Boaz Nishri $^{2} \cdot$ Deborah Cvikel $^{1}$ (D) \\ Published online: 1 August 2019 \\ (c) The Author(s) 2019
}

\section{Correction to: Journal of Maritime Archaeology https://doi.org/10.1007/s11457-019-09233-0}

The article "Finite Element Analysis of Shell-First and Longitudinally Reinforced FrameBased Wooden Ships," written by Nathan Helfman, Boaz Nishri, and Deborah Cvikel was originally published electronically on the publisher's Internet portal (currently SpringerLink) on May 20, 2019, without open access.

With the authors' decision to opt for Open Choice, the copyright of the article changed on August 2019 to (C) The Author(s) 2019 and the article is forthwith distributed under the terms of the Creative Commons Attribution 4.0 International License (http://creativeco mmons.org/licenses/by/4.0/), which permits use, duplication, adaptation, distribution, and reproduction in any medium or format, as long as you give appropriate credit to the original author(s) and the source, provide a link to the Creative Commons license, and indicate if changes were made.

The original article has been updated.

Open Access This article is distributed under the terms of the Creative Commons Attribution-NonCommercial 4.0 International License (http://creativecommons.org/licenses/by-nc/4.0/), which permits any noncommercial use, distribution, and reproduction in any medium, provided you give appropriate credit to the original author(s) and the source, provide a link to the Creative Commons license, and indicate if changes were made.

Publisher's Note Springer Nature remains neutral with regard to jurisdictional claims in published maps and institutional affiliations.

The original article can be found online at https://doi.org/10.1007/s11457-019-09233-0.

Nathan Helfman

nathan.helfman@gmail.com

1 Department of Maritime Civilizations and the Leon Recanati Institute for Maritime Studies, University of Haifa, 3498838 Haifa, Israel

2 CorFlow Ltd. Aerodynamic and Flow Technologies, Haifa, Israel 